\title{
Leadership Impact on Employee Motivation of Kindergarten's Staffs in Rangpur
}

\author{
Most. Ayasha Siddiqua \\ Assistant Professor, Department of Management Studies, Begum Rokeya University, Rangpur, Bangladesh.
}

\begin{abstract}
:
The study focuses on building the relationship between leadership roles and employee motivation among the kindergarten staff. Purposively 20 kindergartens have been considering from 50 participants. Through a questionnaire, primary data has been gathered. The motivation multifactor questionnaire style has been used because of finding a broader view of the leadership impacts. Data has been analyzing by using the SPSS- 23 version. A statistical tool like factor test, percentile has been used to show the relationship between motivation and leadership. The study reveals a profound relationship between the leadership attitude and the some commit mental issues of motivation. Leadership roles like trust, initiatives, and share vision encourage creating value-driven inspiration and continuous development as positive impacts on the employee. Although it not the complete packages to satisfy the staff but mostly as per their level.
\end{abstract}

Keywords: leadership, motivation, employee commitment, kindergarten

DOI: $10.7176 /$ RHSS/10-17-07

Publication date:September $30^{\text {th }} 2020$

\section{Introduction and Background}

While this examination attracts leadership styles to progress further comprehension on the basic systems that empower leaders to act in a dictatorial or groundbreaking way and influence representative motivation, their conduct, and subsequently, their hierarchical situated ventures, every association, similar to each group requires administration (Malott, 2010). The initiative permits directors to influence worker conduct in the association (Vance,2006) . Hence, spurred representatives are one of the most significant aftereffects of compelling administration. (Ndururu , 2019), fruitful directors are additionally influential leaders since they impact workers to help achieve hierarchical objectives. Notwithstanding, accomplishing hierarchical goals isn't sufficient to keep representatives inspired, yet assisting workers to conduct their own and vocation objectives is a significant aspect of their motivation. Leadership and motivation are intelligent. Leadership ability is dependent upon, and regularly characterized as far as leaders' capacity to inspire adherents toward aggregate objectives or an aggregate strategic vision). The more propelled the supporters, the more successful the leader; the more compelling the leader, the more inspired the devotees (Chait et al.,2011).

The inventiveness is a "social impact measure that is important for the achievement of cultural and hierarchical objectives; it is both prominent in its nonattendance and strange in its quality - natural but then hard to"(Bennett et al.,2009). (Burns ,1977) Leaders comprehend that they have power and that they understand the wellspring of their capacity: their position, their ability to compensate and to constrain; their aptitude; and their intrigue and appeal. They impact their devotees' conduct through correspondence, bunch elements, preparing, rewards, and order. There are numerous leadership styles, specifically: groundbreaking, situational, despotic, visionary, and magnetic leadership. While this examination is to draw from the imperious and groundbreaking leadership styles to progress further comprehension of the hidden components that

Empower leaders to act in an absolutist or groundbreaking way; and influence representative motivation, conduct, and like this, their authoritative arranged endeavors (Nadeem,2020). The paper expects to set up the initiative style in propelling the school personnel to be focused on their work. Leadership is mind-boggling because it is concentrated in various manners that involve multiple definitions. For this situation, it very well may be characterized as the cycle of a leader conveying thoughts, picking up the acknowledgment of the vision, and rousing adherents to help and execute the ideas through others (Kressle, 2003). A leader can consistently impact others and may not be a director, though someone else can have initiative characteristics and be a chief.

There are three sorts of Managerial Leadership aptitudes, to be specific: Technical abilities, Interpersonal Skills, and Decision-Making abilities (Guillén,2001). Specialized talents are worried about the capacity to utilize strategies and procedures to play out an undertaking; Interpersonal talents, then again, center exclusively around the capacity to comprehend, impart and function admirably with people and gatherings through creating compelling connections (Kanungo et al.,1992). Finally, dynamic aptitudes include the capability to conceptualize circumstances and select choices to tackle issues and make the most chances (Lengnick-Hall,2009). This study has attempted to find the relationship between leadership and motivation among the kindergarten staff in Rangpur.

\section{Method and Material}

This study has based on the primary and, therefore, the secondary data. This study of principals' views of leadership 
style as an influencing factor on motivating and inspiring the teaching staff to perform better in their respective academic duties was conducted among 20 Kindergartens. From these 20 Kindergartens, 50 teaching staff were selected to participate for purposive sampling total sample size is 50. Teaching staff were selected to participate during this study because teaching may be a core duty during this enterprise. The participants were conveniently selected; however, the sample was chosen in such how that more participants came from Kindergartens that weren't performing above the provincial benchmark. the info was obtained from the faculties and every one the teaching staff were encouraged to finish the questionnaire. Identifying similar phrases, relationships between themes, distinct differences between target blocks and customary self-administered questionnaires containing structured items, were applied. Items within the questionnaire focused on leadership and motivation in assisting and supporting teaching staff. additionally, an issue was asked on how the principal manages and motivate the varsity the varsity. Closed questions helped in eliciting specific information, while open-ended questions enabled the respondents to precise their views freely and without restriction. Because the methodological paradigm applied during this research may be a survey method with the questionnaire constructed within the Likert-type approach, starting from 1 to 5 , the study could also be classified as quantitative research.

Throughout the study every effort was made to take care of high ethical standards. Anonymity and confidentiality were protected within the least times with a radical explanation in the sort of a cover letter provided to all or any participants, detailing the aim of the study. theoretically researcher consider some factor like 1 . Feel right about being in 2. Supervision on attaining the target, 3. Leadership Capacity, 4. Rewards on attaining the target, 5. Value focuses, 6. Motivation focuses. Data analysis and interpretation were done using the interactive model of quantitative data analysis which first involved sorting or sifting through the info and sequences., it had been important that the mass of knowledge collected should then be reduced to a format suitable for analysis. The respondents' responses were then encoded consistently with the emerging themes using the SPSS V 23 program. Data were analyzed by descriptive statistics, like percentages, frequency, and, therefore, the KMO and Bartlett's Test to check for consistency of the factor data, among other things, the reliability of describing the impact and, therefore, the leadership style in these Kindergartens.

\section{Leadership and Motivation}

Self-motivation could be a progression of things that drive people's conduct. Motivation is normally seen as either characteristic or extraneous (Medun,2001). Inborn motivation is accomplishing something that is intrinsically charming and fulfilling, though outside motivation depends on outer components like getting rewards or maintaining a strategic distance from discipline (McClelland,1997). There are two parts of accommodating Leadership: first might be a pledge to the undertaking; second and similarly significant, might be a worry for individuals (Togneri et al., 2003). Compelling leaders can rouse employee's in a partnership and progressively improve profitability (Gauthier-September,2006). Leaders need to make energy among employees so as that they're going to see importance and sense inside the different jobs they're playing (Golema,2003). Both energy and motivation are key fixings in motivation. They will be developed by acceptable initiative style (Preece,2009). Leadership style, which endeavors to share and grant the significance of the vision of an association with the remainder of representatives, is critical inside the technique for spurring employees (Beazley et al.,2002). When each representative comprehends the shared objective and goals of an association as cherished in its vision explanation, it'll be very simple for leaders to make motivation in them. The compelling leadership style will affirm that employees are very much educated regarding the effect of the vision and crucial the association (Kouzes et al.,2010). They should be caused to feel a vital part of the whole cycle of making progress additionally as appreciating the gainful results of their responsibility. When this is frequently regularly accomplished, employees are getting the chance to be propelled because they have alluring incidental advantages as well as because they have a bright future close by the association (Riggio, 2008). Destitute Leadership will cover relevant data from employees (Blanchard,2018). This may cause them to have a method of distance from the association and died down persuaded. It's general information that individuals will, in general, have the individual drive on the off chance that they know very well that they have something to exploit or be excited for either inside the short or future (Markus, 2004). At the point when such worker connection is accomplished, at that point crafted by a pacesetter goes to be smooth. Leaders who comprehend the undeniable reality that they have to shape a top to the bottom working relationship with representatives are regularly effective (Heifetz \& Linsky,2017). It's out of being close with individual specialists that it will be anything but difficult to distinguish and tackle their issues at work and in this manner rouse them. The association between Leadership and motivation that has barely been investigated inside the past examined. The path during which the two parts of hierarchical conduct employees is critical in guaranteeing positive development during a business. The initiative could likewise be a sort of social impact which is created during a strong gathering of individuals. On the off chance that a group chief chooses to assign obligations to the subordinate staff, at that point, this may be depleted how that it will have the least involved positive effect 
on every employee. That is frequently now where the contrast among wonderful and wasteful initiative is watched. For instance, a changed leader will, above all else, judge the office and capability of each colleague at that point delegate task in like manner. Employees ought to be relegated obligations in regions of intrigue and ability all together that they will be inspired as they appreciate playing out their responsibilities (Behn,2009). An initiative style which will remain in general force an errand on employee's without assessing their ability will frequently miss the point. Employees who are constrained to do duties are not really inspired, and this means dreary execution (Guglielmi et al.,2013).

Motivation could likewise be an objective situated trademark that enables a private to accomplish his goals. It pushes an individual to take a stab at achieving their dreams. A chief must have the correct initiative characteristics to impact motivation $($, 2012). Notwithstanding, there is no particular outline for motivation. As a pacesetter, one should keep an open viewpoint on the element. Knowing the different needs of subordinates will settle on the emotional cycle simpler. Both a representative additionally, as a supervisor must have leadership and motivational aspects. An influential leader must have a piece of extreme information on motivational elements for other people (Chemers.2014).

They're more likely than not comprehended the basic needs of representatives, friends and bosses. Leadership is utilized as to how of persuading others. Urging people to ask it engaged with arranging and significant issues goal methodology inspires them as well as shows the complexities of these key dynamic elements (Taylor,2010). Also, it'll help everybody to ask a far superior comprehension of their part inside the association. The correspondence goes to be unambiguous and may positively pull in affirmation and gratefulness from the leader (Passarelli,2015).

Creating good and solidarity unquestionably includes a fundamental effect on the prosperity of an organization (Turne,2001). The metal or soul of a private comprises their ethical texture. A leader's activities and choices influence the confidence of his subordinates (Marquis\& Huston,2009) Henceforth, he ought to recall his decisions and exercises. Solidarity is the spirit of the association. The leader ought to affirm his employees appreciate playing out their obligations as a group and make themselves an area of the association's arrangements (Avolio \& Bass,2001). A pacesetter should step into the shoes of the subordinates and think about things from subordinate's point. He ought to identify with them during troublesome occasions. Relating to their issues makes them more grounded intellectually and inwardly. A significant and testing position achieved instils how of achievement among representatives. The boss must cause their representatives to feel they're playing out a meaningful work that is essential for the association's prosperity and achievement. This motivational perspective drives them to fulfil their objectives. Apart from the research gap, this study attempted to find the level of the impact of employee motivation of kindergarten staff in Rangpur.

\section{Results and Discussions}

KMO and Bartlett's Test

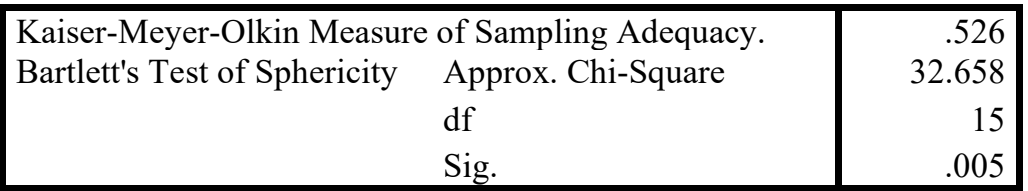

Figure: 01

Source: Author's compilation

Figure 1 indicates that the KMO measure's value is 0.526 , which is more than 0.5 , and therefore, it can be accepted, and the significant level is also high because it is less than 0.005 . it has been clarifying that the items of motivation nearby enormously significant for the staff matter.

Feel good about being in

\begin{tabular}{|ll|r|r|r|r|}
\hline & Frequency & Percent & Valid Percent & Cumulative Percent \\
\hline Valid & not at all & 11 & 22.0 & 22.0 & 22.0 \\
& once in a while & 4 & 8.0 & 8.0 & 30.0 \\
& Sometimes & 19 & 38.0 & 38.0 & 68.0 \\
fairly often & 15 & 30.0 & 30.0 & 98.0 \\
frequently, if not always & 1 & 2.0 & 2.0 & 100.0 \\
Total & 50 & 100.0 & 100.0 & \\
\hline
\end{tabular}

Figure: 02

Source: Author's compilation

From the table where most of the respondent's aggress that sometimes they feel right about being in the organization that carries $38 \%$, on the other $30 \%$ believe that they feel right about being in somewhat respect of 
their headmaster or head of the organization. Only $2 \%$ feel frequently feel good at the boss's supervisor, $22 \%$ shown negative not at all, and finally, $8 \%$ believe that it once forms all of the points. Concludingly it has been clear that most of them beveled and concluded to some time they feel instill pride in the organization under the supervisor.

\section{Supervision on attaining target}

\begin{tabular}{|c|c|c|c|c|c|}
\hline & & Frequency & Percent & Valid Percent & $\begin{array}{c}\text { Cumulative } \\
\text { Percent }\end{array}$ \\
\hline \multirow[t]{6}{*}{ Valid } & not at all & 10 & 20.0 & 20.0 & 20.0 \\
\hline & once in a while & 6 & 12.0 & 12.0 & 32.0 \\
\hline & Sometimes & 20 & 40.0 & 40.0 & 72.0 \\
\hline & fairly often & 13 & 26.0 & 26.0 & 98.0 \\
\hline & frequently, if not always & 1 & 2.0 & 2.0 & 100.0 \\
\hline & Total & 50 & 100.0 & 100.0 & \\
\hline
\end{tabular}

Figure: 03

Source: Author's compilation

From the table where most of the respondents aggress that sometimes Supervision on attaining target in the organization that carries $40 \%, 26 \%$ believe that they Supervision on attaining target in somewhat in respect of their headmaster or head of the organization. Only $2 \%$ feel frequently feel good at the Supervision on attaining target, $20 \%$ shown negative not at all, and finally, $12 \%$ believe that it once forms all of the points. Concludingly, it has been clear that most of them revealed and concluded to sometime they Supervision on attaining target on the organization under the supervisor.

\section{Leadership Capacity}

\begin{tabular}{|c|c|c|c|c|c|}
\hline & & Frequency & Percent & Valid Percent & $\begin{array}{l}\text { Cumulative } \\
\text { Percent }\end{array}$ \\
\hline \multirow[t]{6}{*}{ Valid } & not at all & 15 & 30.0 & 30.0 & 30.0 \\
\hline & once in a while & 10 & 20.0 & 20.0 & 50.0 \\
\hline & Sometimes & 14 & 28.0 & 28.0 & 78.0 \\
\hline & fairly often & 9 & 18.0 & 18.0 & 96.0 \\
\hline & frequently, if not always & 2 & 4.0 & 4.0 & 100.0 \\
\hline & Total & 50 & 100.0 & 100.0 & \\
\hline
\end{tabular}

Figure: 04

Source: Author's compilation

Above table, where most of the respondent aggress that not at all 30\% agrees to Leadership Capacity of their boss. On the other $20 \%$ believe that they feel good about Leadership Capacity on acne in a hackerspace of their headmaster or head of the organization. Only $28 \%$ feel sometimes feel good at the boss's supervisor as per the leadership ability, $18 \%$ shown fairly not at all, and finally, $4 \%$ believe that it does not always form all of the points. Concludingly, it has been clear that most of them believe and conclude to not all they about the Leadership Capacity on the organization.

\section{Rewards on attaining target}

Rewards on attaining target

\begin{tabular}{|ll|r|r|r|r|}
\hline & Frequency & Percent & Valid Percent & Cumulative Percent \\
\hline Valid & not at all & 14 & 28.0 & 28.0 & 28.0 \\
& once in a while & 8 & 16.0 & 16.0 & 44.0 \\
Sometimes & 19 & 38.0 & 38.0 & 82.0 \\
fairly often & 9 & 18.0 & 18.0 & 100.0 \\
Total & 50 & 100.0 & 100.0 & \\
\hline
\end{tabular}

Figure: 05

Source: Author's compilation

From the table, where most of the respondents aggress upon that they sometimes Rewards on attaining target, the percentage is 38\%. Again 9\% believe that they Reward on attaining targets in respect of their headmaster of the head of the organization. Only $18 \%$ feel Rewards somewhat on attaining the boss's target, $16 \%$ shown once at all, and finally $28 \%$ believe it is not all. It has been clear that most of them beveled and concludes to a sometimes 
level about the Rewards on attaining target as per the leadership. Value focuses

\begin{tabular}{|ll|r|r|r|r|}
\hline & \multicolumn{3}{|c|}{ Value focuses } \\
\hline Valid & Frequency & Percent & Valid Percent & Cumulative Percent \\
& not at all & 10 & 20.0 & 20.0 & 20.0 \\
& once in a while & 4 & 8.0 & 8.0 & 28.0 \\
Sometimes & 24 & 48.0 & 48.0 & 76.0 \\
fairly often & 12 & 24.0 & 24.0 & 100.0 \\
Total & 50 & 100.0 & 100.0 & \\
\hline
\end{tabular}

Figure: 06

Source: Author's compilation

Above the table, most of the respondents argue that sometimes they Value focus issues in the organization that is $48 \%$. Furthermore, r $24 \%$ believe that relatively, in the case of Value focuses on the organization's headmaster. Only $8 \%$ feel in ace a while at the bosses' supervisor per the Value focus, $20 \%$ shown negative not at all. It has been clear that most of them beveled and concluded that they feel about the supervisor's Value focuses

Motivation focuses

\begin{tabular}{|c|c|c|c|c|c|}
\hline & & Frequency & Percent & Valid Percent & $\begin{array}{c}\text { Cumulative } \\
\text { Percent }\end{array}$ \\
\hline \multirow[t]{6}{*}{ Valid } & not at all & 7 & 14.0 & 14.0 & 14.0 \\
\hline & once in a while & 10 & 20.0 & 20.0 & 34.0 \\
\hline & Sometimes & 23 & 46.0 & 46.0 & 80.0 \\
\hline & fairly often & 5 & 10.0 & 10.0 & 90.0 \\
\hline & frequently, if not always & 5 & 10.0 & 10.0 & 100.0 \\
\hline & Total & 50 & 100.0 & 100.0 & \\
\hline
\end{tabular}

Figure: 05

Source: Author's compilation

From the table, where most of the respondent's aggress that sometimes Motivated focuses in the organization that carries $46 \%$. on the other $10 \%$ believe that they feel right about being in relatively respect for their headmaster Motivated focuses. Only 10\% feel frequently feel good at the boss's supervisor as per the Motivated focuses, $14 \%$ shown negative not at all, and finally. Moreover, $20 \%$ believe that it once forms all of the points; it has been clear that most of them beveled and concludes to sometime Motivated focuses on the organization under the supervisor

\section{Conclusion:}

Leadership is one of the first worries of authoritative partners in the contemporary business world. Specialists have discovered that administration style affects hierarchical execution and achievement. Individual leadership styles have been proclaimed as being more skilled than others of tending to the difficulties that new chiefs face. A worker, just leader, must have leadership and inspirational qualities. A leader must have a piece of intensive information on persuasive variables for other people. The comprehensively comprehend the fundamental needs of representatives, companions and his bosses. The initiative is utilized as a method for propelling others. The leadership style that is acknowledged by the kindergarten staff will spur, rouse and impact them when choices and issue emerge. Moreover, these styles can make positive, hierarchical duty and advance employment execution. The school director or head through his initiative style can generally increment hierarchical responsibility by giving prizes. The vast majority of the cases the respondent felt at some point conduct that demonstrated that it not always but rather shows the realities generally happening to advance the great degree of initiative in kindergarten of Rangpur from the motivation and leadership role relativity.

\section{References:}

Avolio, B. J., \& Bass, B. M. (Eds.). (2001). Developing potential across a full range of Leadership Tm: Cases on transactional and transformational leadership. Psychology Press.

Beazley, H., Boenisch, J., \& Harden, D. (2002). Continuity management: preserving corporate knowledge and productivity when employees leave. John Wiley \& Sons.

Behn, R. (2009). Leadership counts: Lessons for public managers from the Massachusetts welfare, training, and employment program. Harvard University Press.

Belasen, A. T. (2012). Developing women leaders in corporate America: Balancing competing demands, transcending traditional boundaries. ABC-CLIO. 
Bennett, T., Savage, M., Silva, E. B., Warde, A., Gayo-Cal, M., \& Wright, D. (2009). Culture, class, distinction. Routledge.

Blanchard, K. (2018). Leading at a higher level: Blanchard on leadership and creating high performing organizations. FT Press.

Burns, J. M. (1977). Wellsprings of political leadership. The American Political Science Review, 71(1), 266-275.

Chait, R. P., Ryan, W. P., \& Taylor, B. E. (2011). Governance as leadership: Reframing the work of nonprofit boards. John Wiley \& Sons.

Chemers, M. (2014). An integrative theory of leadership. Psychology Press

Gauthier-September, A. (2006). Developing collective leadership: Partnering in multi-stakeholder contexts. Leadership is global: Bridging sectors and communities, 1-20.

Goleman, D. (2003). What makes a leader. Organizational influence processes, 82, 229-241.

Guglielmi, D., Simbula, S., Mazzetti, G., Tabanelli, M. C., \& Bonfiglioli, R. (2013). When the job is boring: The role of boredom in organizational contexts. Work, 45(3), 311-322.

Guillén, M., \& González, T. F. (2001). The ethical dimension of managerial leadership two illustrative case studies in TQM. Journal of Business Ethics, 34(3-4), 175-189.

Heifetz, R., \& Linsky, M. (2017). Leadership on the line, with a new preface: Staying alive through the dangers of change. Harvard Business Press.

Kanungo, R. N., \& Misra, S. (1992). Managerial resourcefulness: A reconceptualization of management skills. Human Relations, 45(12), 1311-1332.

Kouzes, J. M., \& Posner, B. Z. (2010). The truth about leadership: The no-fads, heart-of-the-matter facts you need to know. John Wiley \& Sons.

Kressler, H. (2003). Motivate and reward. Basingstoke: Palgrave Macmillan.

Lengnick-Hall, C. A., \& Beck, T. E. (2009). Resilience capacity and strategic agility: Prerequisites for thriving in a dynamic environment (pp. 39-69). San Antonio, TX: UTSA, College of Business.

Malott, C. (2010). Policy and research in education: A critical pedagogy for educational leadership (Vol. 4). Peter Lang.

Markus, M. L. (2004). Technochange management: using IT to drive organizational change. Journal of Information technology, 19(1), 4-20.

Marquis, B. L., \& Huston, C. J. (2009). Leadership roles and management functions in nursing: Theory and application. Lippincott Williams \& Wilkins.

McClelland, D. C. (1987). Human motivation. CUP Archive.

Medun, B. D. (2001). The factors that may influence a faculty members' decision to adopt electronic technologies in instruction (Doctoral dissertation, Virginia Tech).

Nadeem, S., \& Siddiqui, D. A. (2020). How HR Practices influence Managers and Organisational Ambidexterity in Pakistani Firms: The Mediatory role of Self-Efficacy and Motivation in a Multilevel Integrated Framework. Available at SSRN 3683340.

Ndururu, T. N. (2019). Impact of Charismatic Leadership Style on Employees' Performance within Cooperative Bank of Kenya Limited (Doctoral dissertation, United States International University-Africa).

Passarelli, A. M. (2015). Vision-based coaching: optimizing resources for leader development. Frontiers in Psychology, 6, 412.

Preece, J., \& Shneiderman, B. (2009). The reader-to-leader framework: Motivating technology-mediated social participation. AIS transactions on human-computer interaction, 1(1), 13-32.

Riggio, R. E., Chaleff, I., \& Lipman-Blumen, J. (Eds.). (2008). The art of followership: How great followers create great leaders and organizations (Vol. 146). John Wiley \& Sons.

Taylor, P. J. (2010). Unruly complexity: Ecology, interpretation, engagement. University of Chicago Press.

Togneri, W., \& Anderson, S. E. (2003). Beyond Islands of Excellence: What Districts Can Do To Improve Instruction and Achievement in All Schools. A Project of the Learning First Alliance [and] A Leadership Brief.

Turner, B. S., \& Rojek, C. (2001). Society and culture: Scarcity and solidarity. Sage.

Vance, R. J. (2006). Employee engagement and commitment. SHRM foundation, 1-53. 